Johnson, J.A. \& Moore, W.W. (1969) Small changes in left atrial pressure and plasma anti-diuretic hormone titres in dogs. American Journal of Physiology, 217, 210.

Kleeman, C.R.J., Koplowitz, M.H., Cutler, M.R. \& Dowling, J.T. (1960) Mechanism of impaired water excretion in adrenal and pituitary insufficiency. II. Interrelationships of adrenal corticosteroids and anti-diuretic hormone in normal subjects and in diabetes insipidus. Journal of Clinical Investigation, 39, 1472.

Koeford-Johnsen, V. \& Ussing, H.H. (1953) The contributions of diffusion and flow to the passage of $\mathrm{D}_{2} \mathrm{O}$ through living membranes. Acta Physiologica Scandinavica, 28, 60 .

LeE, J., Jones, J.J. \& BarRaClough, M.A. (1964) Inappropriate secretion of vasopression. Lancet, ii, 792.

Rosenow, E.C., Segar, W.E. \& ZeHR, J.E. (1972) Inappropriate anti-diuretic hormone secretion in pneumonia. Mayo Clinical Proceedings, 47, 169.

Schwartz, W.B., Bennett, W., Curelop, S. \& Bartter, F.C. (1957) A syndrome of renal sodium loss and hyponatremia probably resulting from inappropriate secretion of anti-diuretic hormone. American Journal of Medicine, 23, 529.

Postgraduate Medical Journal (May 1974) 50, 312-313.

\title{
The use of anticoagulants in bacterial endocarditis
}

\author{
JoHN A. KANIS \\ B.Sc., M.R.C.P.(U.K.) \\ Royal Infirmary of Edinburgh
}

\section{Summary}

Early experience in the treatment of bacterial endocarditis with penicillin suggested that the addition of anticoagulants might improve results. This paper reports a patient with bacterial endocarditis who died from embolic cerebral damage after initiation of treatment with heparin. The evidence suggests that anticoagulants were responsible for her death and that bacterial endocarditis is a relative contra-indication to anticoagulant therapy.

\section{Introduction}

First successes with penicillin treatment in bacterial endocarditis were published in 1943 (Herrell, 1943; Florey and Florey, 1943). In 1945 Loewe reported on fifty-four patients in whom simultaneous administration of both penicillin and of heparin had proved successful in the treatment of bacterial endocarditis. Heparin was advocated (Leading article, 1946) to arrest the deposition of platelets and fibrin which would otherwise form a protective nidus for bacterial growth. Dawson and Hunter (1945) published two series of cases, in the first of which they used penicillin and heparin and in the second penicillin alone. The results of the two series were equally favourable and later experience (Bloomfield, Armstrong and Kirby, 1944; Christie, 1945; Mokotoff et al., 1944) confirmed that anticoagulant was unnecessary when adequate penicillin doses were used. It was concluded that early reports of successes with heparin and penicillin, where treatment with penicillin alone had failed, were due to inadequate penicillin doses. Thill and Meyer (1947), using penicillin in combination with anticoagulants, found a high incidence of fatal cerebral haemorrhage, leading them to suppose that $\varnothing$ the use of anticoagulants was contra-indicated in this disease.

Thus the climate of medical opinion that was perpetuated from work in the middle 1940s was that not only were anticoagulants unnecessary, but that their use was strongly contra-indicated in bacterial endocarditis (Gavey, 1951; Toohey, 1959; Ziment, 1969) because of an increased danger of haemorrhage in areas infarcted by emboli. In 1966, this view was challenged by Lerner and Weinstein (1966), who state that 'These drugs should be used for the same reasons that they are administered to persons who do not have endocarditis.' However, the following case reports a patient with bacterial endocarditis who was given anticoagulants and who died from an intracranial haemorrhage, suggesting that this more recent viewpoint may be in error.

\section{Case report}

The patient, a 29-year-old nurse, had had rheumatic fever at the age of 14. A mitral murmur had been noted at the time but subsequent penicillin prophylaxis had not been started. Two years prior to presentation she suffered one transient episode of acute pulmonary oedema after a 'flu-like' illness, but required no long term medication thereafter. On admission she gave a 4-week history of lethargy and tiredness following an upper respiratory tract infection. Two weeks later she had developed intermittent rigors, night sweats and an unproductive cough. Three days before admission she became 
orthopnoeic coincident with the onset of rapid and irregular palpitations.

Examination showed marked skin pallor and slight finger clubbing. There was no splenomegaly or urinary abnormalties. Cadiomegaly and atrial fibrillation with an apical rate of $200 / \mathrm{min}$ was present and associated with bilateral basal crepitations. She had murmurs of both mitral stenosis and regurgitation.

Her rapid atrial fibrillation was treated successfully with intra-muscular digoxin and systemic heparinization. Investigation of the presumed bacterial endocarditis included immediate and regular blood cultures. Six hours after admission she complained of a mild occipital headache and her temperature had risen to $39 \cdot 2^{\circ} \mathrm{C}$. She rapidly became confused, hypotensive, her temperature fell to below normal and her conscious level deteriorated. Further management was intended to treat both the development of a septic cerebral embolus or of bacteraemic shock. She was given antibiotics to cover a wide range of organisms, with hydrocortisone and a mannitol infusion. Two hours following her collapse, she developed respiratory arrest and thereafter required assisted ventilation. Though her pulse rate, blood pressure and arterial blood gases remained satisfactory, she developed areflexia and fixed dilated pupils over the following hours.

Results that later became available showed the patient to have a mild normochromic normocytic anaemia. Blood cultures on four occasions prior to chemotherapy grew Streptococcus viridans. Her ASO titre was not raised. Examination of cerebro-spinal fluid following her collapse was normal. An electroencephalogram undertaken $48 \mathrm{hr}$ after admission to hospital showed no cerebral activity and assisted ventilation was discontinued.

Post mortem examination demonstrated an extensive left cerebellar haemorrhage. The heart showed severe endocarditis involving the mitral valve. Culture of valve vegetations grew penicillin sensitive Streptococcus viridans. Small septic infarcts were demonstrated in both kidneys.

\section{Discussion}

Atrial fibrillation is an uncommon finding in bacterial endocarditis (Cates and Christie, 1951). The use of anticoagulants is widely accepted in the treatment of rapid atrial fibrillation (Wood, 1968). Although it has been suggested that anticoagulants are contra-indicated in bacterial endocarditis, Lerner and Weinstein (1966) have recently suggested that this is not so.

Whilst clinical evidence of intracranial embolization is seen in $15 \%$ of patients with bacterial endo- carditis (Cates and Christie, 1951), death attributable to this complication is much less frequent (Cates and Christie, 1951; Freidberg, Goldman and Field, 1961; Pankey, 1962; Volger, Dorney and Bridges, 1962). Experience of this patient, in whom the control of rapid atrial fibrillation was covered with heparin resulting in a fatal intracranial haemorrhage, re-emphasizes the risks when anticoagulants are given in bacterial endocarditis. This report suggests that anticoagulants should remain contraindicated in the presence of bacterial endocarditis.

\section{Acknowledgment}

I am grateful to Dr R. M. Marquis for his helpful criticism and permission to report on this patient under his care.

\section{References}

Bloomfield, A.L., Armstrong, C.D. \& Kirby, W.M.M. (1944) A study of penicillin failures. Journal of the American Medical Association, 127, 129.

CATES, J.E. \& Christie, R.V. (1951) Subacute bacterial endocarditis. Quarterly Journal of Medicine, 44, 93.

Christie, R.V. (1945) Penicillin in bacterial endocarditis. Lancet, ii, 123.

Dawson, M.H. \& Hunter, T.H. (1945) The treatment of subacute bacterial endocarditis with penicillin. Journal of the American Medical Association, 127, 129.

Florey, M.E. \& Florey, H.W. (1943) General and local administration of penicillin. Lancet, i, 387.

FriedberG, C.K., Goldman, H.M. \& Field, L.E. (1961) Study of bacterial endocarditis. Archives of Internal Medicine, 107, 6.

GAVEY, C.J. (1951) The prevention and treatment of thrombophlebitis. Practitioner, 166, 260.

Herrell, W.E. (1943) Further observations on the clinical use of penicillin. Proceedings of the Staff Meeting Mayo Clinic, 18, 65.

LeAding ARTICle (1946) Success in bacterial endocarditis. Lancet, i, 390.

LERNer, P.I. \& WeInSTeIN, L. (1966) Infective endocarditis in the antibiotic era. New England Journal of Medicine, 274, 323.

LOEWE, L. (1945) The combined use of penicillin and heparin in the treatment of subacute bacterial endocarditis. Canadian Medical Association Journal, 52, 1.

Mokotoff, R., Katz, L.N., Brams, W.A. \& Howell, K.M. (1944) Penicillin failures. Journal of the American Medical Association, 126, 1167.

Pankey, G.A. (1962) Acute bacterial endocarditis at the University of Minnesota Hospitals, 1939-1959. American Heart Journal, 64, 583.

THILl, C.J. \& MEYER, O.O. (1947) Experiences with penicillin and Dicumarol in the treatment of subacute bacterial endocarditis. American Journal of Medical Science, 213, 300.

ToOHey, M. (1959) Oral anticoagulants. Practitioner, 183, 641.

Volger, W.R., Dorney, E.R. \& Bridges, H.A. (1962) Bacterial endocarditis. American Journal of Medicine, 32, 910.

Wood, P. (1968) Diseases of the heart and circulation, 3rd Edition. Eyre and Spottiswoode: London.

ZiMENT, I. (1969) Nervous system complications in bacterial endocarditis. American Journal of Medicine, 47, 593. 